\title{
Study On Mycotoxin Contamination For Egyptian Rice During Post Harvest Processing
}

1- University of Sadat City

Ahd A. Saleh ${ }^{1}$, M. A. El-Howeity ${ }^{2}$, H.Galal ${ }^{2}$,A. A. Abo Hagar ${ }^{3}$

2 Environmental studies and Research Inst., University of Sadat City, Egypt.

3- Environmental Studies and Research Institute, Evaluating Natural Resources and Planning Department of Natural Resources, University of Sadat City, Egypt

\section{ABSTRACT}

This study aimed to introduce a survey and assessment of contaminants of mycotoxins (aflatoxin) in the Egyptian rice through the stages of preparation after the harvest and until reaching to the consumer. The rice samples were collected from (Dakahleya, Kafr El-Sheikh, and ElSharka), stored rice in flat. Samples divided, graded and kept in cloth bags and stored for nine months period at ambient environmental conditions. Results of the study dealt with chemical properties of hulled rice before storing, moisture content, Ash percentage, nitrogen free extract (NFE\%) percentage, physical properties of hulled rice, weight per 1000 kernels (gm), hardness $(\%)$, color of hulled rice, Microbial properties of rice after different storing periods, total count of fungi for hulled rice of different governorates subject of the study, Aflatoxin in storage periods for hulled rice. Results of chemical properties indicated that increase of moisture content in ElSharka rice compared with others and protein percent was higher in Kafr El-Sheikh compared to Dakahleya or ElSharka rice. Physical properties of hulled rice showed that, the quality of rice with storage days was the best for Dakahleya rice compared with other rice after 180 days. Microbial properties showed that, Fungus count as $\log (\mathrm{Cfu} / \mathrm{g})$ for the hulled rice after 180 days for the highest value for Kafr El-Sheikh is 3.24, the second rank recorded for Dakahia governorate 3.12 while the lowest value was in Sharkia governorate (1.5). It is noticed that aflatoxin showed after180 from storage days and increased at 270 day from storage rice and was higher in Sharkia followed by Dakahia rice then Kafr El-Sheikh rice.

Key words: Chemical properties, Microbial properties Aflatoxin, storage periods, hulled rice

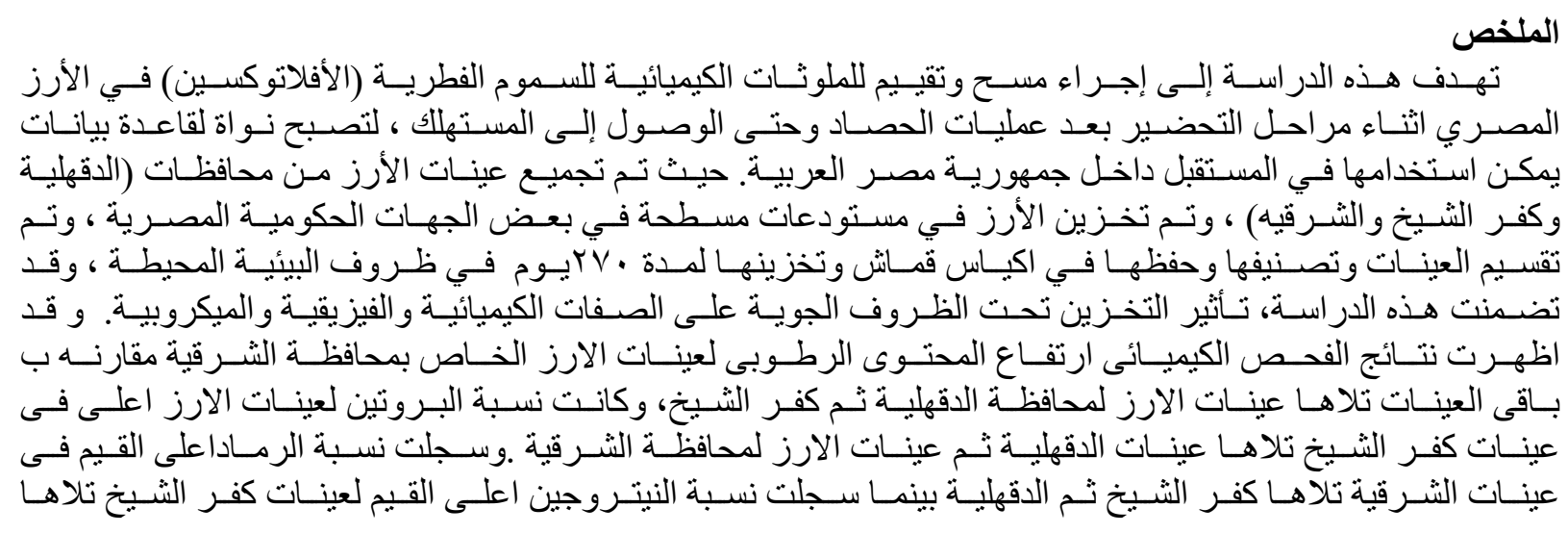




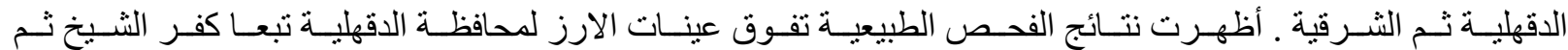

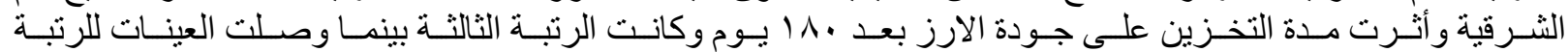

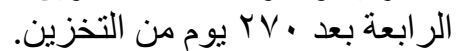

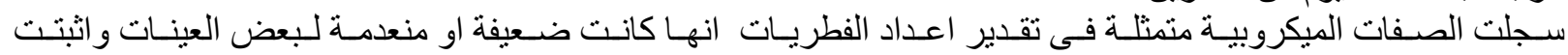

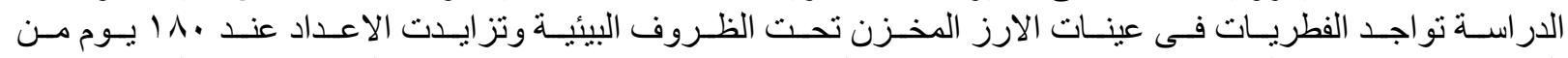

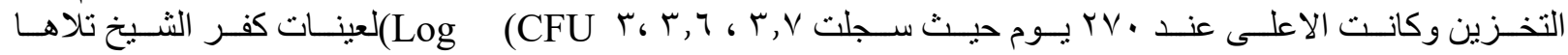

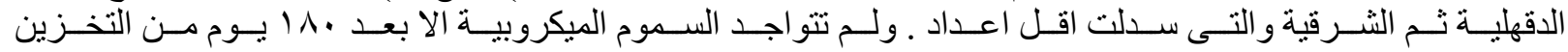

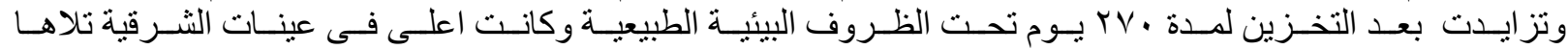

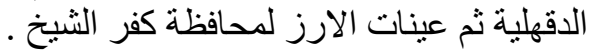

الكلمــات الدالــة: الصــفات الكيميائيــة ــ الصــفات الطبيعيــة ــ الصــفات الميكروبيــة ــالســموم الميكروبيــة ـ فتــرة التخزين

\section{INTRODUCTION}

Rice in Egypt is the largest rice producer in the Middle East region and it is one of the most important agricultural crop which Egypt export to different countries around the world "about 60 country" due to the Egyptian competitive prices comparing to other exporter countries like Italy, Spain, Australia and USA. The overall positive turnout would be in spite of numerous setbacks, including above normal temperatures in Egypt and erratic rains across the southern and eastern parts of the continent. Although these factors were behind poor crop results in important producers such as Egypt, the United Republic of Tanzania and Madagascar, overall conducive growing conditions boosted output to new heights in Western Africa, largely offsetting the losses incurred in the rest of the region. (FAO, 2016)

The 2016 season is well advanced in Eastern and Southern Africa, where producers are in the process, or getting ready, to collect the season's main crop. The season has only started in Egypt and will not go into full swing in Western Africa before June/July. Early expectations for the 2016 campaign see paddy production in the continent expanding by 2 percent to 29.1 million tons (19.0 tons, milled basis). Egyptian farmers, with the help of Egyptian researchers, are producing one of the world's highest rice yields.

According to records, the average Egyptian rice farm yield in 2011 - 2012 was 3.5 tons per Fadden with total production about 5.5 million tons/ year. Rice consumption per person in Egypt in 2012 was $45 \mathrm{~kg} / \mathrm{yr}$ while the total local consumption was around 4.5 million ton/ year so the total amount available for export is about 1.3 million tons/ year and it is increasing year after year due to the improving of the productivity which pay the attention of the shipping agencies and make them to determine regular trips between the Egyptian exporting ports and the importing countries ports. Thus, improving the productivity of rice systems would contribute to hunger eradication, poverty alleviation, national food security and economic development as rice provides $27 \%$ of dietary energy supply and $20 \%$ of dietary protein intake. (FAO, 2016) 
Mycotoxin contamination often occurs in the field prior to harvest. Post-harvest contamination can occur if the drying is delayed and during storage of the crop if moisture is allowed to exceed.

Critical values for mold growth. Delayed harvest in rainy weather frequently leads to grain's sprouting on the panicle, particularly for non-dormant japonica rice. The fungi, A. Flavus, A. Parasiticus, A. Niger, and A. Ochraceus, have been reported earlier by Reddy et al., (2009), which A. flavus have been identified as the primary quality deterrent, producing aflatoxin contaminated seeds when in storage .

Reddy (2008) explored the incidence of Aspergillus sp. in 1,200 rice samples consisting of paddy (675) and milled rice (525) collected from 43 locations in 20 ricegrowing states across India. The seeds collected were either from areas exposed to different weather conditions or stored at various storage conditions, namely seeds from the crop exposed to heavy rains and floods, seeds from submerged zones.

Rice stored in warehouses and mills is known to harbor toxigenic fungal species. Many cultivars are grown in different rice ecosystems. Aspergilli are the major contaminants in rice seeds produced and stored under high humidity conditions. Level of fungal contamination at different sites of seeds that were stored for more than a year using samples of 18 cultivars collected across rice ecosystems in India. In seed component plating, Aspergilli dominated as externally borne contaminants in unsterilized seed, kernel, hull, and kernel powder. After surface sterilization, only a limited number of colonies were obtained from seed, hull, kernel, and kernel powder in tests with seeds.

A high incidence of A. flavus was found in the seed microflora of rice bran. Rough rice samples from warehouses in Brazil were milled to separate polished rice, bran, and rice hull to evaluate microflora in each of the samples. The most frequent contaminants in those samples belonged to the genus Aspergillus. Sales (Reddy, et al., 2006)

In India, the level of mycotoxins in rice differs from one location to another. This is due to various factors like temperature, relative humidity, and agricultural practices. In general, hot and humid conditions are very favorable for the growth of toxigenic fungi and mycotoxin production in agricultural produce. Many countries regulate specific mycotoxins and most countries try to limit exposure to the toxins. There are several systematic surveys on mycotoxin levels in different agricultural commodities including rice. (Krishnamurthy and Shashikala, 2006).

Aflatoxins are potent toxic, carcinogenic, mutagenic, immunosuppressive and teratogenic agents produced as secondary metabolites by A. flavus and A. Parasiticus (Krishnamurthy and Shashikala, 2006).

These toxins are named after the fungus producing them, e.g. "A" from the genus name Aspergillus, "fla" from the species name flavus added to toxin to give the name aflatoxin. There are 18 different types of toxins in the aflatoxin group identified. 
Among these aflatoxin toxins, the major members are aflatoxins B1, B2, G1, G2, M1 and M2 (Kiswii , 2009).

Aflatoxin B1 is produced most abundantly and is the most toxic followed by G1, B2 and G2. Aflatoxins B1, B2, G1 and G2 are classified as Group I human carcinogens whereas $\mathrm{M} 1$ is classified as Group 2B probable human carcinogen (Krishnamurthy and Shashikala, 2006).

Aflatoxin is extremely durable under most conditions of storage, handling and processing of seeds or in foods or feeds made from contaminated seeds. It is very heat stable and will withstand temperatures up to boiling. Aflatoxin levels in maize may decline in storage, but may still be present after 7 years .Aflatoxin becomes more prevalent, and therefore more of a food safety concern, during a drought because low rainfall and high temperatures encourage the growth and survival of the molds that produce the toxins. Crops stressed by drought and high temperatures and/or weakened by insect or other damage, are more susceptible to mold growth and subsequent aflatoxin contamination. The aflatoxin producing molds can grow on crops in the field, poorly dried harvested crops in storage and processed food and feed products (Abbas, 2005).

\section{Statement of the Problem:}

Consumption of food contaminated with aflatoxins has caused both chronic and acute aflatoxicosis that has resulted in loss of livestock and human life. The presence of fungal infection of rice in the field usually leads to lower yields for food and fibre crops, nutrient losses, alteration of organoleptic properties and diminishment of product shelf life in the market leading to adverse economic effects. Further, the use of synthetic chemicals to control storage fungi particularly Aspergillus species in stored rice has been restricted due to their carcinogenicity, teratogenicity, high and acute residual toxicity, long degradation period, environmental pollution and their adverse effects on food and side effects on human health.

\section{Objectives:}

A survey and assessment of chemical contaminants of mycotoxins (aflatoxin) in the Egyptian rice through the stages of preparation after the harvest and until reaching to the consumer, to become the nucleus of a database that can be used in the future in the Arab Republic of Egypt.

\section{Materials and methods}

The Rice Samples had been collected from (Dakahleya, Kafr El-Sheikh, and ElSharkya), stored Rice in flat warehouses in Some Egyptian Governmental was hi industrial. Samples divided, graded and kept in cloth bags and stored for Nine months period at ambient environmental condition. 


\section{Experimental Design:}

The Rice samples had been used as experimental groups (Dakahleya, Kafr ElSheikh, and El-Sharkya Rice sample had been used as control group. $25 \mathrm{~kg}$ of each type of Rice had been collected. 3 samples of each type of Rice had been prepared for grading test ( 3 samples $\mathrm{x} 4$ periods of $0,30,60,90,270$ days).

\section{Weather conditions:}

The study had been conducted in the period from $1^{\text {st }}$ August to the $30^{\text {th }}$ November, 2017. This period is divided into three sub-intervals (0-30-60 -90-180-270 days) as shown in Table (1)

Springfield device Model\# 91551-W had used for measuring both temperature and humidity.

Table (1): Mean of the temperature and relative humidity through the previously mentioned period

\begin{tabular}{|l|l|l|l|}
\hline Period & $0-30$ days & $30-60$ days & $60-90$ days \\
\hline Average temperature (V) & 34 & 30 & $29{ }^{\circ} \mathrm{c}$ \\
\hline Average Humidity (\%) & 58.5 & 57.5 & $58 \%$ \\
\hline
\end{tabular}

Grains had been divided through Cargo divider equipment (in USA standards) (this equipment divides samples about $10 \mathrm{~kg}$ to $2.5 \mathrm{Kg}$ ) and Berner divider (in this equipment divides samples about $2.5 \mathrm{~kg}$ to $1050 \mathrm{~g}$ ) in Feed Grain Inspection Lab, Agricultural Research Center, Giza, Egypt.

Grains were graded by using Carter Day Grading Machine (Dockage Tester Serial No 1712 U.S.A) in Feed Grain Inspection Lab, Agricultural Research Center, Giza, Egypt.

Packaging: Cloth bags were used for manual packaging of the used samples.

Storage: The samples of the experimental and control groups had been stored in Laboratory Silo that satisfies exposure to all Egyptian environmental conditions.

Period of storage: The period is 9 months started from 23/7/2017 and ended by $22 / 4 / 2018$

Protein was determined according to Kjeldahl method Association of Official Analytical Chemists.

\section{Determination of Aflatoxins:}

Aflatoxins were determined in rice samples, according to (Anon, 1990).

Aflatoxin $\mu \mathrm{g} / \mathrm{kg}$ sample $=\mathbf{S} \times \mathbf{V} \times \mathbf{Y} / \mathbf{X} \times \mathbf{W}$ 
Where: $\mathbf{S}=\mu$ l aflatoxin equal unknown; $\mathbf{Y}=$ Concentration of Aflatoxin $\mathrm{B}_{1}$ standard $\mu \mathrm{g} / \mathrm{ml} ; \quad \mathbf{V}=$ of final dilution of sample; $\mathbf{X}=\mu \mathrm{l}$ sample extraction spotted giving fluorescent intensity equal to $\mathbf{S}\left(\mathrm{B}_{1}\right.$ standard); $\mathbf{W}=\mathrm{g}$ sample.

\section{Results and discussion}

\section{For the chemical properties}

Chemical properties has been measured for both dehulled and hulled rice Abefore storing.

The study indicated that the highest moisture content for hulled rice was recorded in Sharkia governorate, while moisture content in hulled rice in both Dakahlia and Kafr El-Sheikh are approximately equal and this result is similar regarding to the dehulled rice in the three governorates for each period (Fig. 1).

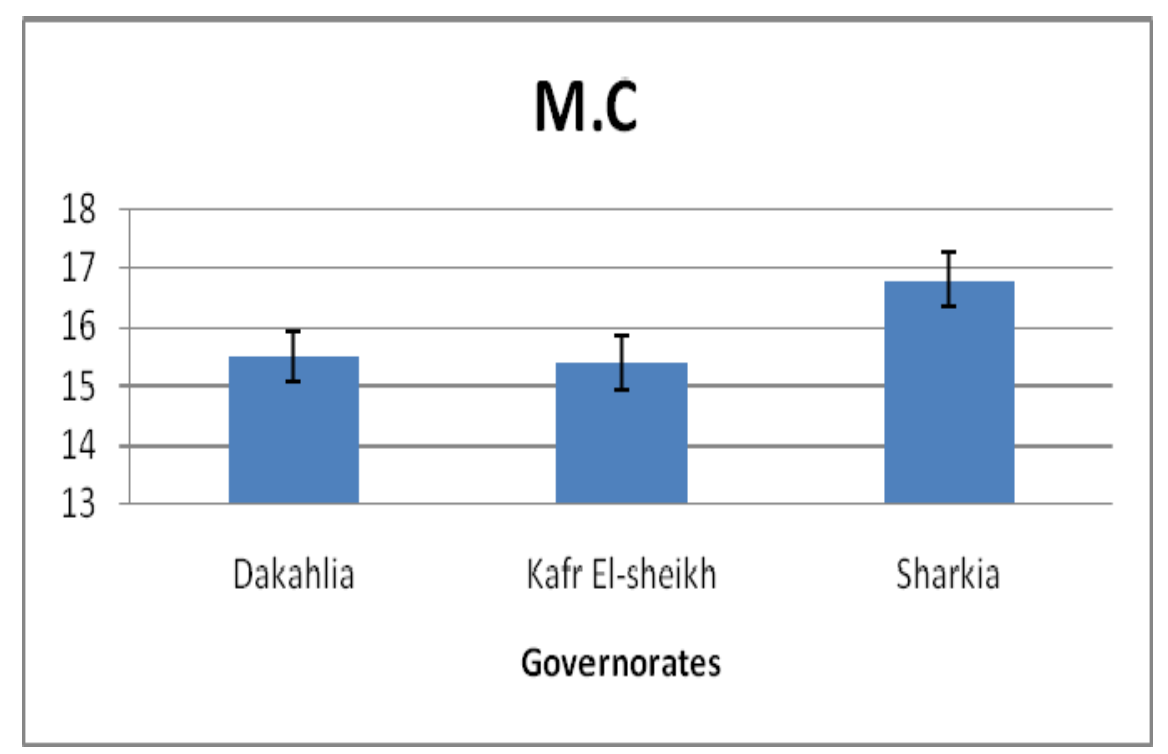

Fig (1): Moisture content in hulled rice according to the governorates

\section{Regarding the Protein percentage}

Protein percentage was also measured for hulled rice in the three governorates (Dakahlia, Kafr El-Sheikh and Sharkia) Fig.(2), the study indicated that the highest protein content appeared in hulled rice in Kafr El-Sheikh governorate and then in Sharkia and Dakahlia respectively. Also, the protein percentage was measured for dehulled rice in the three governorates (Dakahlia, Kafr El-Sheikh and Sharkia), the results indicated that the highest protein content appeared in dehulled rice in Kafr ElSheikh governorate and then in Dakahlia and Sharkia respectively. But it is also noticed that the variations in protein percentage is relatively slight. This is accorded well with the study conducted by (Gewaily, et al, 2018) that indicated the high protein percentage for Sakha 101 in Kafr El-Sheikh. 


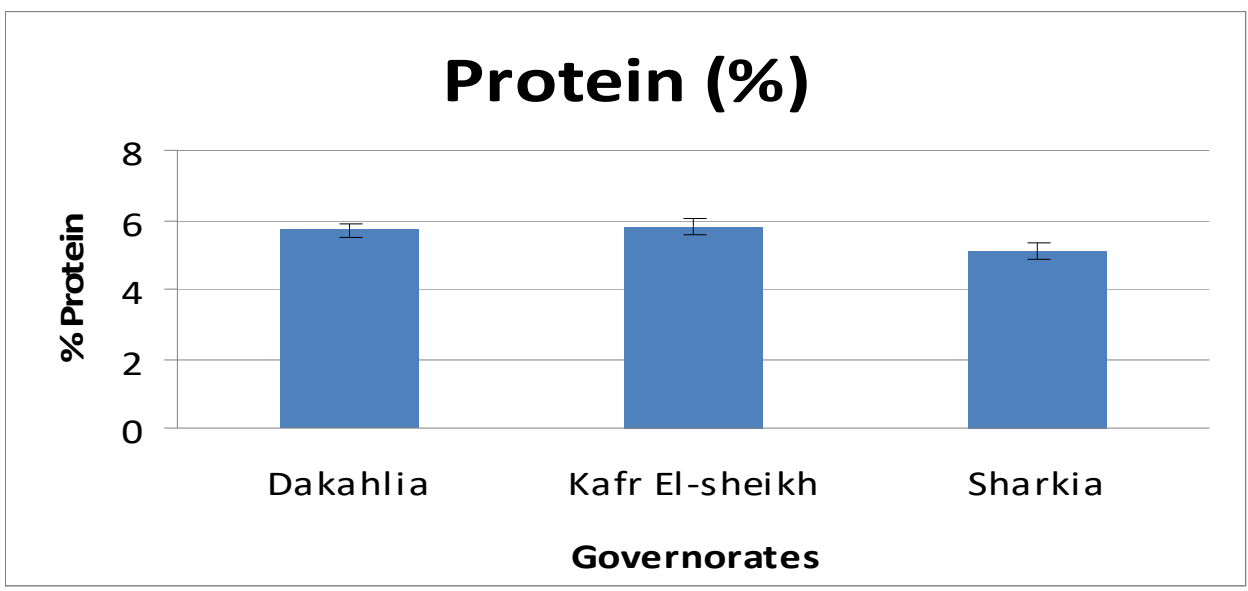

Fig (2 ) protein \% of hulled rice for different governorates of the study

Regarding to ash percentage, it was measured for hulled rice in the three governorates (Dakahlia, Kafr El-Sheikh and Sharkia), the results illustrated in (Fig 3) showed that the highest ash \% appeared in hulled rice in Kafr El-Sheikh governorate and then in Sharkia and Dakahlia respectively. But it is also noticed that the variations in fat percentage is relatively slight.

Also, ash percentage was measured for dehulled rice in the three governorates (Dakahlia, Kafr El-Sheikh and Sharkia), the results indicaed that the highest ash \% appeared in dehulled rice in El-Sahrkia governorate and then in Kafr El-Sheikh and Dakahlia respectively.

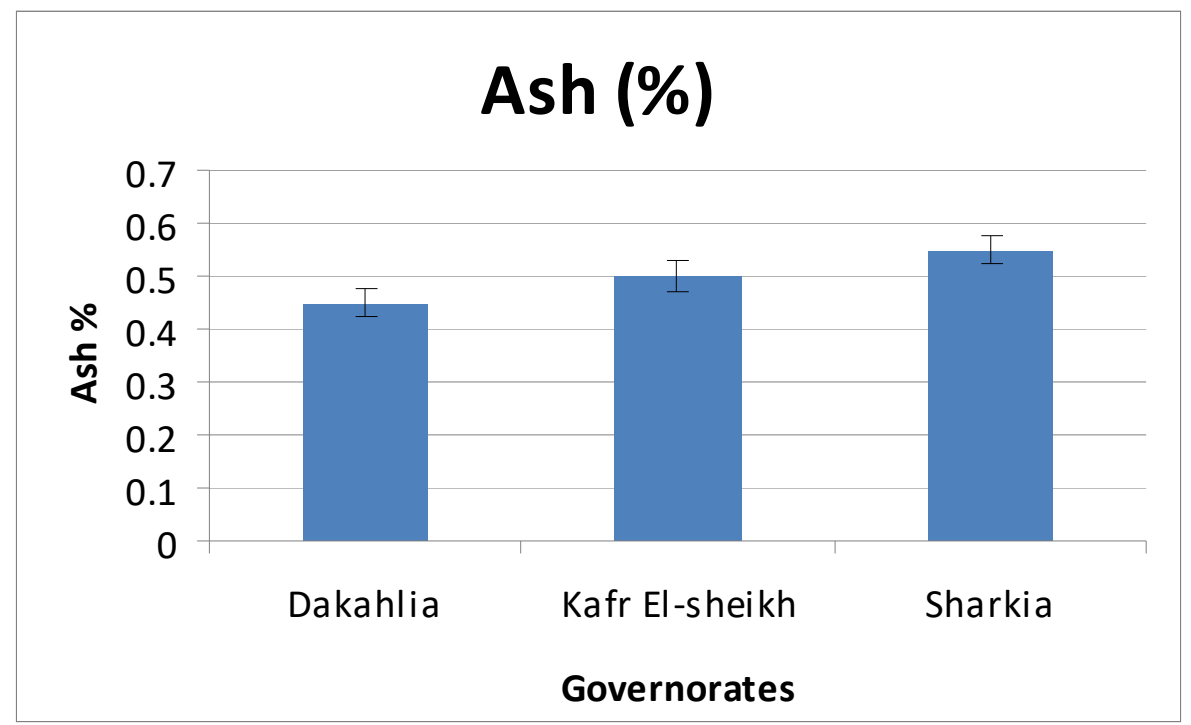

Fig (3): Ash \% of hulled rice for different governorates of the study

Regarding nitrogen free extract percentage, it was measured for hulled rice in the three governorates (Dakahlia, Kafr El-Sheikh and Sharkia), the results in( Fig 4) indicated that the highest NEF \% appeared in hulled rice in Kafr El-Sheikh and then in Sharkia and Dakahlia governorate respectively. 


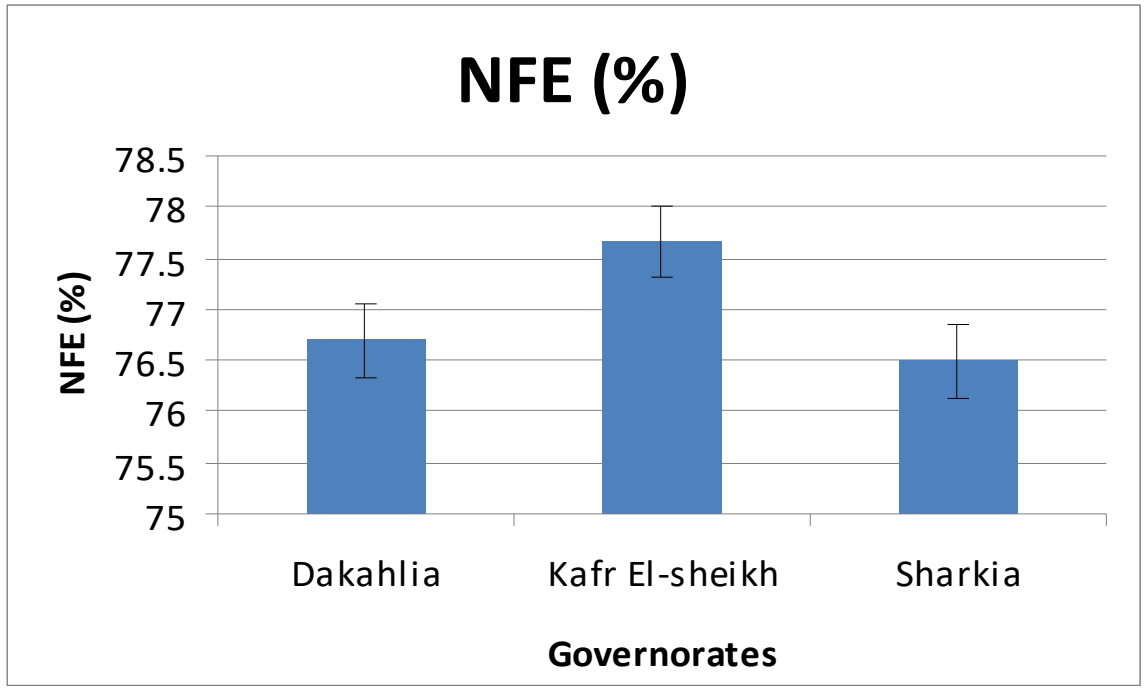

Fig (4): NFE \% of hulled rice for different governorates of the study

\section{Physical properties}

\section{- Physical properties for hulled rice}

Weight per 1000 kernels, hardness \% and color were estimated for hulled rice at the beginning for the three governorates (Dakahlia, Kafr El-Sheikh, and Sharkia). Regarding the weight per 1000 kernels, it is noticed that the highest value for hulled rice was in Dakahlia governorate followed by Kafr El-Sheikh and Sharkia respectively; this may refer to the soil quality and high level of service during agriculture. This accorded well with the study of (Awad-Allah, et al., 2019)

It is also noticed that after 180 days of storage, that the grade of brown rice for processing is grade 3 for all the rice collected from the different zones of the study (Dakahlia, Kafr El-Sheikh and Sharkia). All types of the brown rice are infested. This is also expected as the increase in storage period leads to increase in infestation with different environmental conditions.

It is also noticed that there is an increase in damaged kernel, broken kernels and well -milled kernels. The heat damaged kernel increased to be 2.5 for both Dakahlia and Kafr El-Sheikh and reached to 3.5 for El-Sharkia; this is also expected as the damaged and broken kernels increase as a results of increasing the infestation and humidity.

It is noticed that after 270 days of storage, that the grade of brown rice for processing is grade 4 for all the rice collected from the different zones of the study (Dakahlia, Kafr El-Sheikh and Sharkia). All types of the brown rice are infested. It is also noticed that there is an increase in damaged kernel, broken kernels and well milled kernels than the previous storage period. The heat damaged kernel increased to be 4 for Dakahlia and 4.5 for Kafr El-Sheikh and reached to 5 for El-Sharkia. 


\section{- Microbial properties}

Regarding that $\log (\mathrm{Cfu} / \mathrm{g})$ for the hulled rice recorded in(Table 2) the three governorates were recorded for the highest value for Dakahia is 1.9, the second rank recorded for Kafr El-Sheikh governorate 1.8 while the lowest value was in Sharkia governorate. This refers to the nature of soil in Sharkia governorate.

$\log (\mathrm{Cfu} / \mathrm{g})$ for the hulled rice in the three governorates were recorded after 90 days. The highest value for Kafr El-Sheikh is 3.1, the second rank recorded for Dakahlia governorate is 3 while the lowest value was 2 in Sharkia governorate. This refers to the nature of soil in Sharkia governorate. This may refer to the humidity and bad condition of the flat warehouses as Kafr El-Sheikh governorate is coastal governorate and has higher humidity than the other two governorates.

Table (2) Total count of fungi for hulled Fungi at experimental stages.

\begin{tabular}{|l|l|l|l|l|}
\hline Governorates & Zero time & 90 days & 180 days & 270 days \\
\hline Dakahlia & 1.9 & 3 & 3.12 & 3.6 \\
\hline Kafr El-sheikh & 1.8 & 3.1 & 3.24 & 3.7 \\
\hline Sharkia & 0.4 & 2 & 1.5 & 3 \\
\hline
\end{tabular}

The results also indicated that $\log (\mathrm{Cfu} / \mathrm{g})$ for the hulled rice in the three governorates were recorded after 180 days for the highest value for Kafr El-Sheikh is 3.24, the second rank recorded for Dakahia governorate 3.12 while the lowest value was in Sharkia governorate (1.5). This is expected due to increase of storage period and high humidity and bad condition of the flat warehouses in Kafr El-sheikh as Kafr El-Sheikh governorate is coastal governorate and has higher humidity than the other two governorates.

The study also showed that $\log (\mathrm{Cfu} / \mathrm{g})$ for the hulled rice in the three governorates were recorded after 270 days for the highest value for Kafr El-Sheikh is 3.7, the second rank recorded for Dakahia governorate 3.6 while the lowest value was 3 in Sharkia governorate. This refers to the nature of soil in Sharkia governorate and due to increase of storage period and high humidity and bad conditions of the flat warehouses in Kafr El-sheikh as Kafr El-Sheikh governorate is coastal governorate and has higher humidity than the other two governorates.

Thus, it can be concluded that $\log (\mathrm{Cfu} / \mathrm{g})$ for the hulled rice in the three governorates for the four periods were recorded, It is noticed that the lowest value for the $\log (\mathrm{Cfu} / \mathrm{g})$ was recorded in hulled rice in Sharkia for the different periods ( 0,90 , 180 and 270 days).

The results illustrated in (Fig 5) indicated that the first two periods ( 0 and 90 days) have no aflatoxins while the second two periods (180 and 270 days) included varieties of aflatoxin. The highest value of Aflatoxin recoded in hulled rice of Sharkia for both 180 and 270 days. The second highest values recorded in Dakahlia hulled rice for the two periods (180 and 270 days). The lowest aflatoxin values were recorded for hulled rice in Kafr El-Sheikh for the two periods (180 and 270 days). 


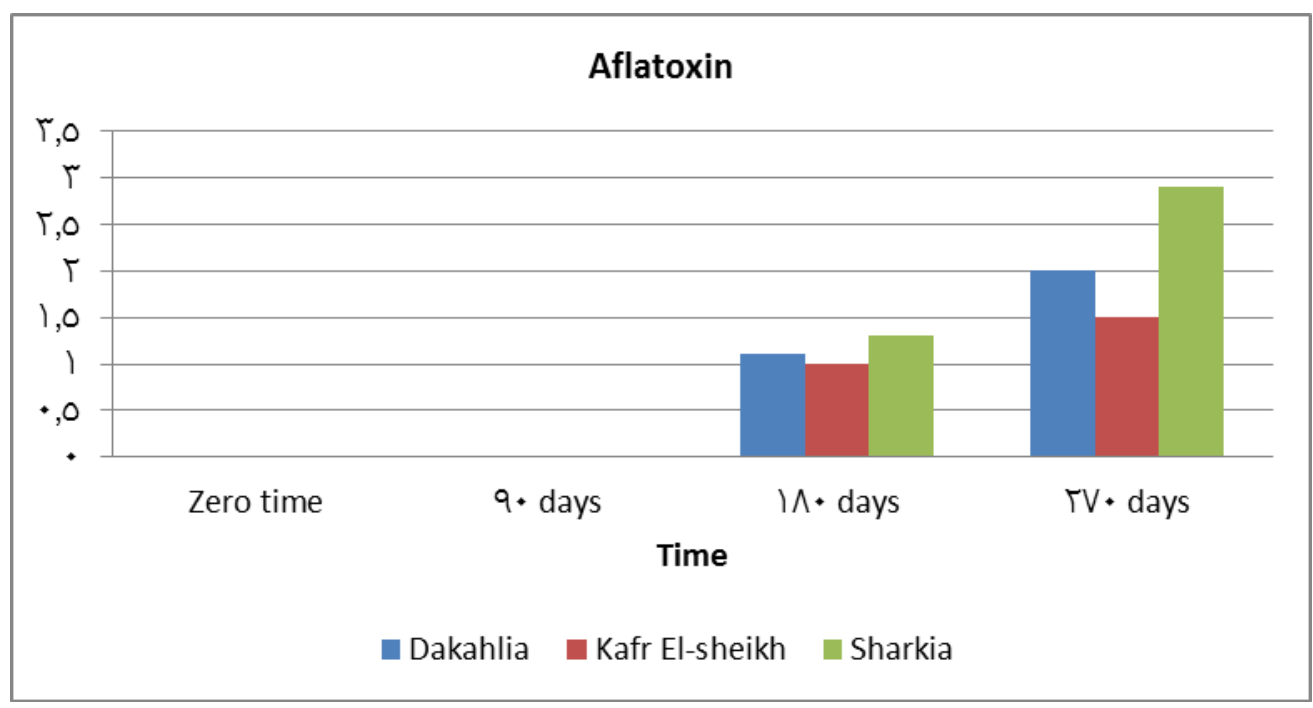

Fig (5) Aflatoxin in storage periods for hulled rice

This can be interpreted as the impact of increasing the storage period in flat warehouses with uncontrolled conditions leads to the increase of the microbial content in the rice. And this accorded well with the study of (Vichet, et al., 2017) that indicated that duration had significant effect on the accumulation of aflatoxin in rice.

\section{CONCLUSION}

The main conclusions in this thesis can be classified into three main categories namely chemical properties, Physical properties and Microbial properties conclusions. It is noticed that after 270 days of storage, that the grade of brown rice for processing is grade 4 for all the rice collected from the different zones of the study (Dakahlia, Kafr El-Sheikh and Sharkia). All types of the brown rice are infested. It is also noticed that there is an increase in damaged kernel, broken kernels and well -milled kernels than the previous storage period. The heat damaged kernel increased to be 4 for Dakahlia and 4.5 for Kafr El-Sheikh and reached to 5 for El-Sharkia.

The results indicated that the first two periods ( 0 and 90 days) have no aflatoxins while the second two periods ( 180 and 270 days) included varieties of aflatoxin. The highest value of Aflatoxin recoded in hulled rice of Sharkia for both 180 and 270 days. The second highest values recorded in Dakahlia hulled rice for the two periods (180 and 270 days). The lowest aflatoxin values were recorded for hulled rice in Kafr El-Sheikh for the two periods (180 and 270 days).

\section{REFERNICS}

1. Abbas, K. H. (2005). Aflatoxins and food safety. CRC press, Taylor and Francis Group. New York pp 67.

2. Kiswii T. M. (2009), Aspergillus flavus and aflatoxin levels in stored maize in eastern Kenya and antifungal activity of some plant extracts, thesis submitted to Kenyatta university. 
3. Krishnamurthy, Y. L. and Shashikala. J. (2006). Inhibition of aflatoxin B1 production of Aspergillus flavus, isolated from soybean seeds by certain natural plant products. Letters in Applied Microbiology 43 (5), 469 - 474.

4. Reddy K.R.N, Reddy C.S, Muralidharan K. (2009) Detection of Aspergillus spp. And aflatoxin B1 in rice in India. Food Microbiol. 26: 27-31.

5. Reddy, K. R. N., Reddy, C. S., and Muralidharan, K. (2006) Characterization of aflatoxin B1 produced by Aspergillus flavus isolated from discolored rice grains. Journal of Mycology and Plant Pathology 35(3), 470-474.

6. Gewaily E.E., W. T Abd El-Rahem, Soheir T. El-Hadide and Maha M. Tawfik (2018). Chemical and Technological Evaluation of Some Egyptian Rice Cultivars, Middle East Journal of Agriculture Research ISSN 2077-4605 Volume : 07 | Issue : 03

7. Awad-Allah, M., Mikhael, B., AbdEL-Rahem, W. (2019). Performance of Different Rice Genotypes under Different Dates of Sowing. Journal of Plant Production, 10(12), 973-981. doi: 10.21608/jpp.2019.71515.

8. Vichet S. , M.Pyseth, P. Tara and G., Martin (2017). Effects of drying and storage management on fungi (Aflatoxin B1) accumulation and rice quality in Cambodia, Journal of Agriculture and Rural Development in the Tropics and Subtropics Vol. 118 No. 1 - 141-148.

9. Food and Agriculture organization of the United Nations(2016) Rice Market Monitor.

FAO.org/fileadmin/templates/est/COMM_MARKETS_MONITORING/Rice/Im ages/RMM/RMM_APR16.pdf. 